
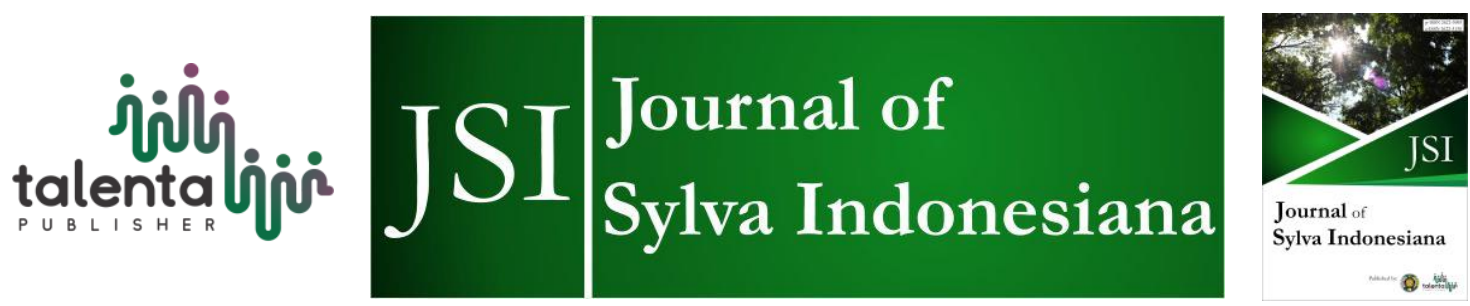

\title{
Estimation Model of Ramin (Gonystylus bancanus) Standing Stock in Peat Swamp Forest: Case Study in Sumatra and Kalimantan
}

\author{
Samsuri $^{1}$, I Nengah Surati Jaya ${ }^{2}$, Tien Lastini ${ }^{3}$, Edwin Setia Purnama ${ }^{4}$ \\ ${ }^{1}$ Department of Forest Management, Faculty of Forestry, Universitas Sumatra Utara, Medan, Indonesia \\ ${ }^{2,4}$ Department of Forest Management, Faculty of Forestry, Bogor Agricultural University, Bogor, \\ Indonesia \\ ${ }^{3}$ School of Life Sciences and Technology, Institut Teknologi Bandung, Bandung, Indonesia
}

\begin{abstract}
Multiple sampling technique was applied to estimate ramin (Gonystylus bancanus) standing stock in peat swamp forest by combining imagery analysis (phase I) and field measurement (phase II). The objectives of this research were to obtain (1) estimation model of stand volume, (2) estimation model of G. bancanus standing stock, and (3) volume of standing stock of G. bancanus in Sumatera and Kalimantan peat swamp forests. The research was conducted in peat swamp forest of Sumatera and Kalimantan Island. ALOS AVNIR image interpretation was completed to obtain crown density and used as independent variable for developing stand volume model. Cluster sampling was used to obtain field data from circle sample plot of 0.1 ha and square sample plot of 0.25 ha. Spatial analysis was conducted to map and calculate standing stock of G. bancanus for Sumatera and Kalimantan Island. Estimation model of stand volume was $\mathrm{Vbf}=0.1851$ Cfield1.05234 (R2 $=0.62)$ for Sumatera peat swamp forest and $\mathrm{Vbf}=3.1163 \mathrm{e} 0.041$ Cfield $(\mathrm{R} 2=0.62)$ for Kalimantan peat swamp forest, respectively. We estimated that standing stock of G. bancanus of peat swamp forest in Sumatra and Kalimantan was 5\% and 2.3\% of the total stand volume, respectively. Base on both the estimation models, standing stock of G. bancanus in Sumatera peat swamp forest was $15,351,063 \mathrm{~m} 3$ and in Kalimantan peat swamp forest was $6,004,874 \mathrm{~m} 3$.
\end{abstract}

Keyword: Gonystylus bancanus, Multiple Sampling, Peat Swamp Forest, Stand Volume, Standing Stock.

Received 20 January 2018 | Revised 24 March 2018 | Accepted 10 April 2018

\section{Introduction}

Indonesia is a country located between Asia and Australia continent and situated between Indian and the Pacific Ocean. Thus, ecological condition is similar to those continents. As an archipelago country, Indonesia has richness tropical biodiversity. Forest types in Indonesia are known to be high in flora and fauna biodiversity [1]. The fauna diversity includes 1,531 bird

\footnotetext{
*Corresponding author at: Universitas Sumatera Utara, Padang Bulan, Medan, 20155, Indonesia E-mail address: samsuri@usu.ac.id
} 
species (17\% of the world diversity), 511 reptile species ( 7.3 of world diversity), 515 mammal species (12\% of world diversity), and 270 amphibian species (fifth in world rank). Furthermore, it is estimated that Indonesia has around 38,000 flora species including 4,000 tree species. This tree species distribute across Indonesia within different types of forests. Some of the species are classified as commercial tree species and attractive tree species with high demand in the global market. One of the attractive tree species is ramin (Gonystylus bancanus) which predominantly can be found in peat swamp and lowland fresh water swamp forest from the Thymelaeceae family [2]. Due to the high demand for ramin timber so that the species sustainability have been threatened. Since 1990 ramin has been categorized as rare timber species. Under various considerations including to sustain this tree species, Indonesia proposed it to include ramin under appendix III CITES (Convention on International Trade in Endangered Species of Wild Fauna and Flora) with a zero quota [2]. CITES approved this proposal and Indonesia started moratorium of Ramin extraction in 2001.

We can find Ramin species in Sumatra Island, Karimata island strain and Kalimantan islands. In Sumatra, ramin can be found in Riau, Bangka Belitung, east coast of Sumatera islands and the Musi River. While in Kalimantan, it can be identified in West Kalimantan, Central Kalimantan and South Kalimantan. Ramin can grow in podzolic soil, peat land and sandy loam soil. Ramin tree generally grow straight and can reach $45 \mathrm{~m}$ height with branch-free bole length around 20$25 \mathrm{~m}$ [3-6]. Ramin can be also identified from its latex that can cause itchy when expose to skin.

Forest management requires valid data and information that can be collected within short amount of time and encompass vast area. It is also applicable in managing ramin where information on standing stock in the forests across Indonesia is a necessary. Thus recent development of methods is focused on achieving this goal. We conducted literature study and interview with related stakeholders who have been involved in forest inventory to obtain current trends of forest inventory and its development opportunity. Application of remote sensing in combination with field survey can be used as forest inventory method. The availability of high quality satellite imagery can produce higher accuracy of analysis compare to those of lower one [7].

Satellite images were identified to obtain images with sufficient spectral and spatial resolution. In this study, we also gave further consideration that images can be accessed easily with relatively low cost involved. The analysis of combining satellite analysis and field measurement was conducted in two islands including Kalimantan and Sumatra. This study aims to obtain G. bancanus standing stock and to develope the standing stock estimation model of ramin in Kalimantan and Sumatra. 


\section{Materials and Methods}

We conducted this research in peat swamp forest of Kalimantan and Sumatra. The research sites are located in Central Kalimantan and Riau.

\subsection{Material and Equipment}

In this study we used materials to conduct the analysis and field survey including medium resolution of satellite imagery Landsat 7 TM and ALOS AVNIR [8]; High resolution of satellite imagery (SPOT 5 panchromatic); topography map; land use map and forest type map (Badan Planologi Kehutanan); peat land distribution (Wetlands International); reports of vegetation survey, soil, geology and other related reports; field working map; and literatures on the research sites.

Equipment used in this research including personal computer, printer, external drive, plotter and other data. Software that was used in ramin inventory is the following: ArcView GIS 3.3 version equipped with plug-in to read image with ER Mapper version 7.0 and ERDAS Imagine version 9.0; and other data analysis software such as SPSS and excel spreadsheet. Field survey equipment's including phi band, compass, GPS, clinometer, measurement tape, height measurement stick, camera and stationary.

\subsection{Data Collection}

\section{A. Image interpretation}

Crown cover interpretation was conducted in 0.04 ha sample plot. Plot was divided into 16 subplots to obtain more details interpretation. In each sub-plots, we examine area with crown and no crown cover. Ratio of area with crown and no crown cover was used to calculate crown density. Crown density can be calculated based on area with crown cover and the plot total area [9]. One of methods that can be applied to measure crown cover density is tree cramming (Figure 1). Crown cover density measured using this method by visualizing location and size of each crown inside the plot. All crown covers were grouped into one group that was enable density calculation.

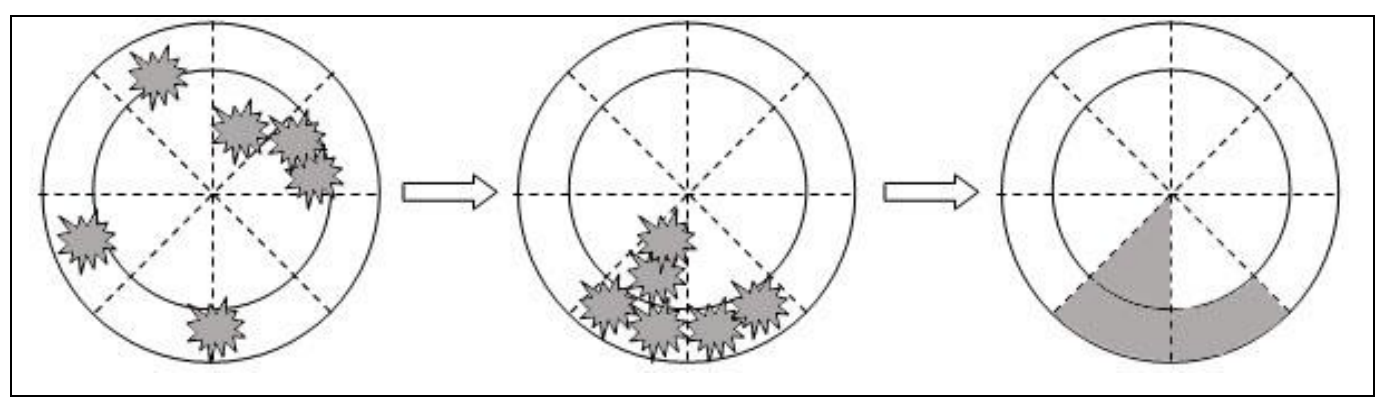

Figure 1 Crown density calculation procedures using tree cramming method 


\section{B. Image interpretation}

Samples were classified according to crown density and peat depth (Figure 2). Systematic with random start was used to establish sample in the field by considering access to get sample plot.

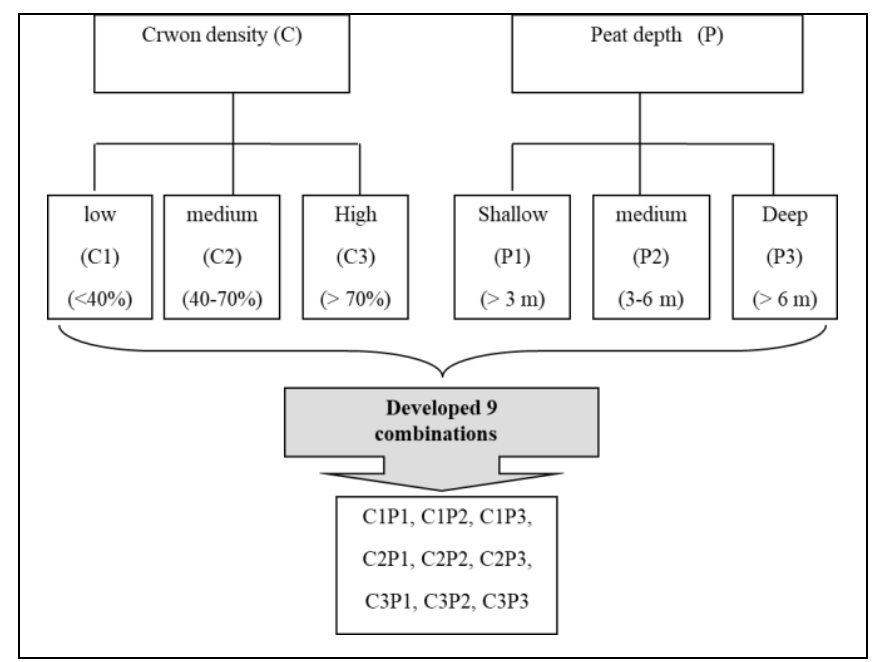

Figure 2 Combinations between crown density and peat depth

Plots were clustered in the field using 4 circle plots of 0.01 ha and square plot of 0.25 ha as presented in Figure 3. Data was collected from 35 clusters or 140 elements, thus in total the sample plot area is 14 ha, for our research site in Kalimantan at the Sebangau National Park. While in Sumatra we collected 37 clusters or 222 elements with the total sample area of 8.88 ha.

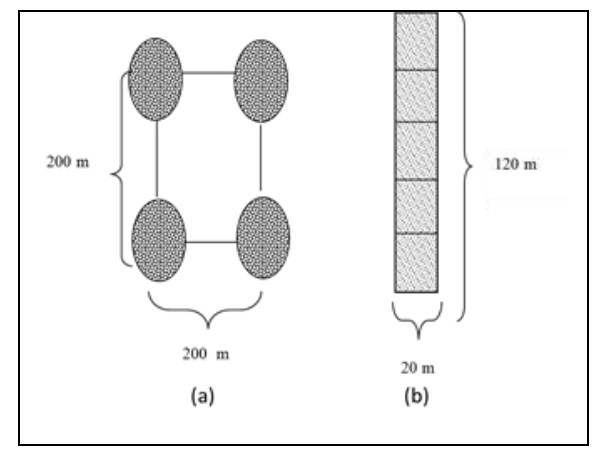

Figure 3 Clusters and sample in the field (a) circle (b) square

We collected two parameters including diameter and height to estimate tree volume [10]. We calculate volume of both Ramin species and other tree species within the sample plot. We used the data of tree volume and crown cover to develop standing stock estimation model of Ramin species.

\section{Model development}

The result of variables obtained from images analysis and field data were then further analyzed using regression [11]. We however have planned several potential estimation models prior to the 
analysis. Crown cover (C) was classified into relatively narrow categories. The result is expected to estimate standing stock of ramin (VT) based on the variables measured in images analysis. The function of measured variables is formulated as the following [12, 13]:

$\mathrm{VT}=\mathrm{f}(\mathrm{C}, \mathrm{D}, \mathrm{N})$ where $\mathrm{C}=$ crown density $(\%) ; \mathrm{D}=$ crown diameter; and $\mathrm{N}=$ tree or crown number.

\section{Model validation}

Models were developed from all research sites were validated before it can be used as estimating model of ramin standing stock. Criteria to validate the model were aggregate error (SA) [14], mean square error (SR), Root Mean Square Error (RMSE), biased (e) Chi-Square to compare estimated volume to the actual volume $[15,16]$.

Each criteria was categorized into 5 classes (class 1, 2, 3, 4 and 5). All scores of each criteria were summarized to obtain the total score. The lower the score is the better the estimation model compare to other models. We used the following validation criteria:

1. Aggregate error

$$
S A=\left(\frac{\sum V_{i(m)}-\sum V_{i(a)}}{\sum V_{i(m)}}\right)
$$

2. Mean square error

$$
S R=\left\{\frac{\sum\left|\frac{V_{i(m)}-V_{i(a)}}{V_{i(m)}}\right|}{n}\right\} \times 100 \%
$$

3. Root mean square error (RMSE)

$$
R M S E=\frac{\sqrt{\sum\left(\frac{V_{i(m)}-V_{i(a)}}{V_{i(a)}}\right)^{2}}}{n} \times 100 \%
$$

4. $\operatorname{Bias}(\mathrm{e})$

$$
e=\left[\sum\left\{\frac{\left(\frac{V_{i(m)}-V_{i(a)}}{V_{i(a)}}\right)}{n}\right\}\right] \times 100 \%
$$


5. Chi-Square analysis

$$
X^{2} \text { cal }=\sum \frac{\left(v_{i(m)}-v_{i[a]}\right)^{2}}{v_{i[(a)}}
$$

where: $\mathrm{Vi}(\mathrm{m})=$ model estimation; $\mathrm{Vi}(\mathrm{a})=$ actual measurement

Hypothesis tested in Chi-Square is as follow:

$\mathrm{HO} \quad: \mathrm{Vm}=\mathrm{Va}$

$\mathrm{H} 1 \quad: \mathrm{Vm} \neq \mathrm{Va}$

Hypothesis testing rule is as follow:

1. If $\chi_{\text {cal }}^{2}<\chi_{\text {table, }}^{2}$, then except Ho which implies that estimated standing stock volume is not significantly different than that of actual measurement. It validates that the selected model can be used as predicting model.

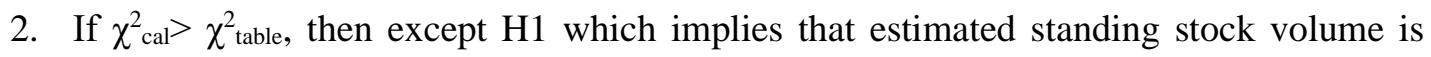
significantly different than that of actual measurement. It indicates that selected model is invalid to be used as predicting model.

\section{E. Standing stock estimation}

Estimation model developed from samples in Riau and Central Kalimantan was used to estimate Ramin standing stock of at islands of Sumatra and Kalimantan. Spatial analysis of land cover, peat depth and stand density was used to develop distribution of ramin standing stock.

\section{Result and Discussion}

\subsection{Stand Structure}

Stand profile was developed to observe horizontal and vertical stand structure based on tree height, azimuth data, and relative position of tree on center of the cluster element. We used Jaya 2009 extension [3] compatible with Arc View 3.2. The research stand profile developed by using Jaya 2009 extension can be seen in Figure 4. 


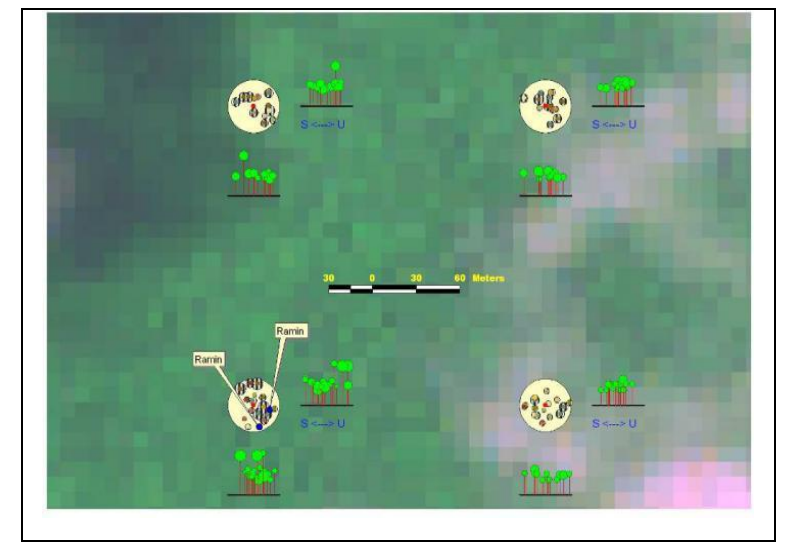

Figure 4 Stand profile of medium crown cover on 3-6 m peat depth

Figure 4 presented that low crown cover in this stand profile was also an indication of relatively low tree number and distribution compare to medium and high crown cover category $[9,17]$.

\subsection{Monogram}

In addition to stand profile, we also develop image interpretation key, usually known as monogram (Figure 5 and 6). In summary, the monogram is defined as a key to the interpretation printed as hard copy of images, which provides information about stand variables (objects) that can be measured or interpreted in the image [18]. Moreover, by using the variables we can display any information on the stand condition.

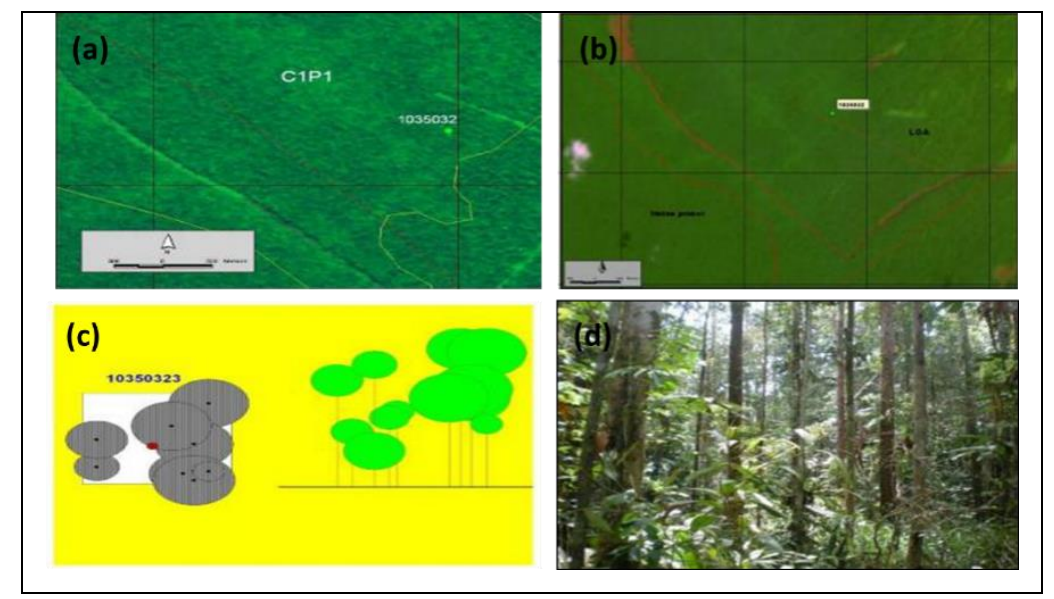

Figure 5 Monogram sample of peat swamp forest (a) ALOS AVNIR (C1P1); (b) land cover identification using landsat; (c) tree profile; and (d) field photo 


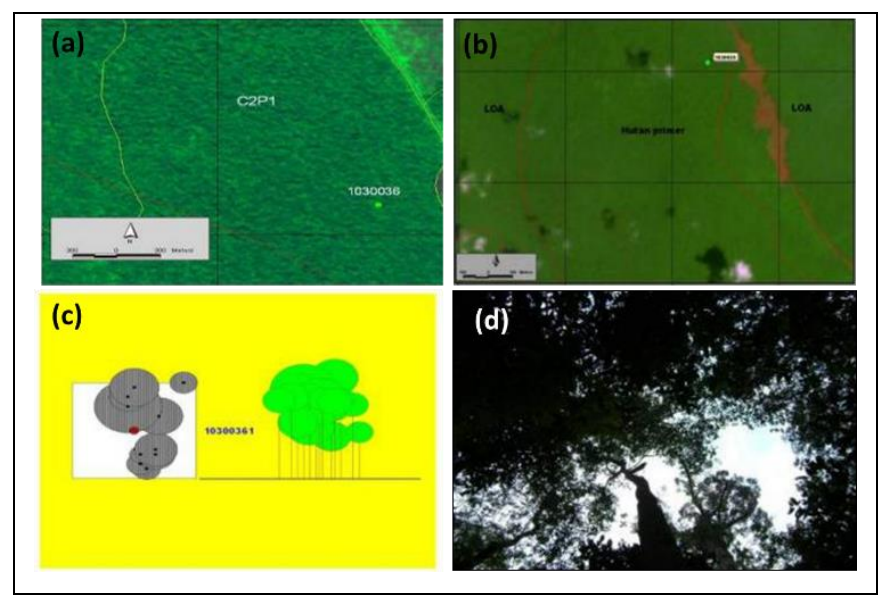

Figure 6 Monogram sample of peat swamp forest (a) ALOS AVNIR (C2P1); (b) land cover identification using landsat; (c) tree profile; and (d) field photo

\subsection{Standing stock estimation model}

Analysis of field data shows that Ramin standing stock in Riau swamp forest was 5\% of total species volume, whereas in Central Kalimantan swamp forest was $2.3 \%$. Ramin tree number was accounted for $4.19 \%$ and $2.64 \%$ of total tree number in Central Kalimantan and Riau respectively (Table 1). We suggested that the result of spatial could be used to estimate the standing stock of Ramin species. It can be done by multiplying the total area of forests land cover for each stratum with its estimated volume.

Table 1 Ratio of tree number and volume between ramin and total all species in peat swamp in Riau (Sumatra) and Central Kalimantan (Kalimantan)

\begin{tabular}{lcccccc}
\hline \multirow{2}{*}{$\begin{array}{c}\text { Research } \\
\text { Site }\end{array}$} & \multicolumn{2}{c}{ Ramin } & \multicolumn{2}{c}{ Total all species } & \multicolumn{2}{c}{ Ratio } \\
\cline { 2 - 7 } & $\begin{array}{c}\text { Individual/ } \\
\text { ha }\end{array}$ & $\mathrm{m}^{3} / \mathrm{ha}$ & $\begin{array}{c}\text { Individual } \\
\text { / ha }\end{array}$ & $\mathrm{m}^{3} / \mathrm{ha}$ & $\begin{array}{c}\text { Tree } \\
\text { number }\end{array}$ & volume \\
\hline Riau & 5.0 & 9.2 & 119.4 & 185.5 & 4.19 & 4.98 \\
\hline $\begin{array}{l}\text { Central } \\
\text { Kalimantan }\end{array}$ & 4.0 & 2.0 & 151.4 & 97.9 & 2.64 & 2.04 \\
\hline
\end{tabular}

We observed that the volume of ramin standing stocks in Sumatra ranged from 193,154 m3 to $386,308 \mathrm{~m} 3$ on shallow peat; $1,351,712 \mathrm{~m} 3$ to $5,406,849 \mathrm{~m} 3$ on medium peat and 0 to $1,879,247$ m3 on deep peat. Standing stocks of Ramin in Kalimantan ranged from 2,464,576 m3 to $5,750,678 \mathrm{~m} 3$ on shallow peat; $1,244,608 \mathrm{~m} 3$ to $2,901,159 \mathrm{~m} 3$ on medium peat, and 491,345 m3 to $1,597,264 \mathrm{~m} 3$ on deep peat.

We found an estimation of standing tree number in Kalimantan ranged between of 2,934,019 to $5,868,039$ trees on shallow peat; $23,919,780$ to $9,146,153$ trees on medium deep peat, and 932,415 to $2,797,246$ trees on deep peat. 


\section{Conclusion}

Estimation model of stand volume was $\mathrm{Vbf}=0.1851$ Cfield1.05234 $(\mathrm{R} 2=0.62)$ for Sumatera peat swamp forest and $\mathrm{Vbf}=3.1163$ e0.041Cfield $(\mathrm{R} 2=0.62)$ for Kalimantan peat swamp forest, respectively. Estimation model of standing stock of G. bancanus for peat swamp forest was ratio model of $5 \%$ stand volume for Sumatera and $2.3 \%$ stand volume of Kalimantan, respectively. Standing stock estimations of Ramin based on spatial analysis in Sumatra and Kalimantan were $7,832,175$ tree or $15,351,063 \mathrm{~m} 3$ and $12,017,687$ tree or $6,004,874 \mathrm{~m} 3$ respectively.

\section{Acknowledgement}

This research project was funded by ITTO CITES project in collaboration with Ministry of Forestry of the Republic of Indonesia in year 2009.

\section{REFERENCES}

[1] K. MacKinnon, G. Hatta, A. Mangalik, and H. Halim, The ecology of Kalimantan: Oxford University Press, 1996.

[2] IUCN Species Survival Commission, IUCN Red List categories, as approved by the 40th meeting of the IUCN Council, Gland, Switzerland, Gland, Switzerland: IUCN, 1994.

[3] I. N. S. Jaya, Analisis Citra Dijital : Perspektif Penginderaan Jauh untuk Pengelolaan Sumberdaya Alam. Teori dan Praktek Menggunakan Erdas Imagine, Bogor: IPB Press, 2009.

[4] I. Soerianegara, and A. Indrawan, Ekologi Hutan Indonesia, Bogor: Departemen Manajemen Hutan, Fakultas Kehutanan IPB, 1982.

[5] T. Samingan, Dendrologi, Bogor: Bagian Ekologi Departemen Botani, Fakultas Pertanian IPB, 1980.

[6] P. Wiroatmodjo, "Hutan ramin (Gonytylus bancanus) di Kalimantan," Majalah Kehutanan Indonesia, vol. 2, pp. 886- 892, 1975.

[7] J. A. Howard, Remote sensing of forest resources: Theory and application, New York (USA): Chapman \& Hall, 1991.

[8] M. Shimada, "ALOS user handbook," Earth observation research center (EORC), Japan Aerospace Exploration Agency (JAXA), Japan, 2007.

[9] D. Pouliot, D. King, F. Bell, and D. Pitt, "Automated tree crown detection and delineation in high-resolution digital camera imagery of coniferous forest regeneration," Remote sensing of environment, vol. 82, no. 2-3, pp. 322-334, 2002.

[10] B. Husch, T. W. Beers, and J. A. Kershaw Jr, Forest mensuration, 4 ed., New Jersey (USA))John Wiley \& Sons, Inc, 2003.

[11] C. Budi, "Penyusunan model penduga volume tegakan dengan foto udara: Studi kasus di HPH PT. Sura Asia Propinsi Dati I Riau," Undergraduate Thesis, Bogor Agricultural University, Bogor, 1988.

[12] Badan Planologi Kehutanan, Pengolahan Citra Resolusi Tinggi dalam Rangka Penaksiran Sumberdaya Hutan Pulau Sumatra, Jakarta, 2007.

[13] Badan Planologi Kehutanan, Pengolahan Citra Resolusi Tinggi dalam Rangka Penafsiran Sumberdaya Hutan di Pulau Kalimantan, Jakarta, 2006. 
[14] S. H. Spurr, Photogrammetry and photo-interpretation. With a section on applications to forestry, New York (USA): The Ronald Press Company, 1960.

[15] R. G. D. Steel, and J. H. Torrie, Principles and procedures of statistics: a biometrical approach, New York (USA): McGraw-Hill, 1986.

[16] N. R. Draper, and H. Smith, Applied regression analysis: John Wiley \& Sons, 1981.

[17] M. Katoh, F. A. Gougeon, and D. G. Leckie, "Application of high-resolution airborne data using individual tree crowns in Japanese conifer plantations," Journal of forest research, vol. 14, no. 1, pp. 10-19, 2009.

[18] F. A. Gougeon, and D. G. Leckie, Forest information extraction from high spatial resolution images using an individual tree crown approach, Information Report BC-X396; Canadian Forest Service, Pacific Forestry Centre, Victoria, BC, Canada, 2003. 